\title{
An Analysis of Indonesian Farmer's Financial Literacy
}

\author{
KARIN AMELIA SAFITRI
}

Department of Insurance Administration and Actuary, Vocational Education Program, UNIVERSITAS INDONESIA, INDONESIA. E-mail: karinamelia@ui.ac.id

\begin{abstract}
The uncertainty of income earned by farmers, namely crop failure with a very high risk, will cause financial problems in their families. The target or respondents of this study are farmers who live in Lahat Regency, South Sumatera. Initial findings indicate that the level of financial inclusion of farmers in the Lahat Regency is still quite low. The purpose of this study is to analyze the level of farmers' financial literacy, identify the components of farmers' financial literacy, and analyze the factors that affect the level of farmers' financial literacy. The research method applied is descriptive analysis and multiple regression. The analysis showed that most of the literate farmers were in the moderately literate category of 47.2 percent and the least of the farmers in the less literate category was 24.5 percent. The financial attitude component gave the largest contribution to the farmers' financial literacy index, which was 0.73 . Besides, the factor affecting the level of financial literacy of farmers is education. The policy implication resulting from this research is the existence of a structured promotion and training of financial literacy for farmers by local governments. In addition, campaigning for the importance of being educated and inviting educated people to start running agricultural business activities.
\end{abstract}

Keywords: Farmers, Financial Literacy, Financial Inclusion, Indonesia

JEL Classification: G53 


\section{Introduction}

Financial literacy is public knowledge and awareness of formal financial institutions, the benefits, features, cost risks, obligations, and rights of a financial product and service. The Indonesian Financial Services Authority or Otoritas Jasa Keuangan (2017) explains that financial literacy is not limited to the understanding of concept, skills, and belief in financial institutions, products, and services, but attitudes and behavior can have an influence in increasing financial literacy which in turn can encourage the realization of public welfare. Meanwhile, OECD (2006) defines that being financially literate individuals are individuals who have knowledge and understanding of the concepts, basic knowledge, and risks of finance, are accompanied by being skilled, motivated, and have the confidence to apply their knowledge and understanding to make financial decisions. effective so that the financial welfare of individuals and society can increase and participate in the economic sector of the country.

Remund (2010) states that financial literacy is a measurement of a person's understanding of financial concepts, and has the ability and confidence to manage personal finances through making appropriate short-term decisions, long-term financial planning, and paying attention to economic events and conditions. Huston (2010) states that financial literacy includes awareness and knowledge of financial instruments and their applications in business and life.

Carpena \& Zia (2011) stated that financial literacy has three dimensions consisting of the skills of financial numeracy, an understanding of the concept of basic finance, and attitudes or perspectives towards financial decisions. Meanwhile, understanding in the context of financial literacy includes concept, knowledge, education, and information about finances and their sources, banking, deposits, pension funds, credit banks, insurance, and taxes.

This person's financial knowledge then develops into financial skills, where financial skills are defined as the ability to apply their financial knowledge in everyday life (Palameta, Nguyen, Hui, \& Gyarmati, 2016). Financial skills allow a person to be able to make rational and effective decisions related to finances and economic resources.

The public is expected to have confidence in financial service institutions and their products and services after having adequate knowledge and skills. Not only for the financial services industry, but each individual must also have confidence in their abilities. This belief includes confidence in carrying out financial activities such as recording investment and expenditure plans, preparing budget plans, and so on (Tustin, 2010).

The knowledge, skills, and financial beliefs possessed by an individual affect their financial attitudes and behavior. Increased knowledge that a person has can have an impact on active participation in financial-related activities, as well as more positive financial behavior for an individual. Besides, the relationship between behavior and one's attitude is seen in someone who has a positive attitude for the long term is likely to show better financial behavior than someone who has a financial attitude for the short term (Atkinson, A.; Messy, 2013).

OECD (2006) explains that without adequate financial literacy, individuals cannot choose savings or investment products that are suitable for themselves and are potentially exposed to the risk of fraud. World Bank researchers Xu \& Zia (2012) found that in developed countries, financial literacy is correlated with retirement planning and is associated with more sophisticated investment habits.

Public knowledge about financial literacy has become a necessity in everyday life so that it becomes a life skill that every individual needs to have in living life in the long term. In addition to welfare, being financially literate is one of the factors to encourage the country's economic progress.

The Financial Services Authority (2017) states that Indonesia has a financial literacy rate of 20 percent, much lower than the Philippines, which reached 27 percent, Malaysia 66 percent, Thailand 73 percent, and Singapore 98 percent. This condition states that Indonesia is a country with a fairly low level of financial literacy. The Household Balance Sheet Survey (BI 2012) shows that the number of households in Indonesia that have a savings account at a bank is only around 49 percent, while the number of households that have access to credit/debt at a bank only reaches 19.58 percent, this 
indicates that the level of access to finance in Indonesia is still quite difficult and the level of inclusion is low.

Indonesia has 7.4 million hectares of agricultural land. The Indonesian agricultural sector has tremendous natural resource potential and high biodiversity due to its strategic geographical conditions and tropical climate. This natural potential makes the Indonesian agricultural sector more advanced and is maximally utilized.

Farmers have a very important and strategic role in the sustainability of the country's economy, especially the Indonesian state, namely helping to meet and produce agricultural products for both food and industrial needs through sustainable food self-sufficiency which is carried out by increasing the production of the national agricultural sector, especially rice. It is realized that increasing the financial literacy of farmer groups is not an easy thing, considering the main problem faced by this group is the absence or low knowledge of knowledge in financial management (Yuwono, Suharjo, Sanim, \& Nurmalina, 2017). By making farmers financially literate, the welfare of their families is achieved and the poverty rate is reduced. The purpose of this research is to analyze the level of financial literacy of farmers where research like this has not been done much.

\section{Literature Review}

Research on financial literacy in Indonesia targeting different groups has produced various findings related to the various factors that influence financial literacy. One of them is research conducted by Yuwono (2017), who stated that farmers in Indonesia, especially the provinces of West Java, East Java, and Central Java, were not more than $6 \%$ who carried out financial expenditure planning which greatly influenced their pattern of financial management. Then they found that there was a positive relationship between farmers' knowledge of financial institutions and the use of financial products. DEFINIT, Support for Economic Analysis Development in Indonesia (SEADI), and the Financial Services Authority (2017) conducting research on 450 sample respondents in the cities of South Jakarta, Medan, and Surabaya. The results, which are classified into basic and advanced financial literacy, show that respondents with basic financial literacy are quite large. The study shows that the higher the education and income level, the higher the financial literacy and male respondents generally have higher financial literacy than women. The survey results also show a correlation between low ownership of complex financial products (stocks, bonds, and mutual funds) and very low advanced financial literacy.

Statistics Indonesia (2015) stated that the agricultural sector is one of the largest contributors to Indonesia's Gross Domestic Product (GDP) after the manufacturing industry and trade hotel and restaurant, which is 12,1 percent. The main actor in this sector is the farmer household, however, in general, the income of farmer families is low and is classified as poor (Sri, 2019). The low and uncertain income obtained by the farming family will indirectly cause problems in the family, not to mention that if farmers experience crop failure, the problems faced by farmers will also increase. This makes farmer families have to prepare themselves to face financial needs in the present and future, in other words, farmers should have high financial literacy. Research by Anwar et al. (2020) found that the financial literacy of farmers in Maros District, South Sulawesi was positively influenced by their income, risk preference, education level, and negatively by the distance between the farmer's house and financial institutions. Meanwhile, farmer age is a factor that does not significantly influence financial literacy. Ravikumar, Sivakumar, Jawaharlal, Palanichamy, \& Sureshkumar (2013) who also studied 100 Indian jasmine farmers in Erode district and 100 jasmine farmers in Madurai district showed that farmers who had been given training and information on financial management had better agricultural financial literacy. Factors of age, education, experience, farm income, years of relationship with the bank, size of land ownership, frequency of bank visits and bank accounts significantly and positively affect farmers' financial literacy. 


\section{Material and Methods}

\subsection{Data}

The data used in this study are primary data obtained through filling out questionnaires. The object of this research focuses on farmers who live in one of the provinces in Indonesia, namely South Sumatra. Because there are so many farmers in the province, the object of research is further reduced to being farmers living in Lahat Regency, South Sumatra. The number of samples selected was as many as 53 respondents selected based on the purposive sampling technique.

\subsection{Methodology}

The analytical method applied in this research is the quantitative descriptive analysis method. The descriptive analysis method is used to describe the demographic characteristics and level of financial literacy of farmers. Meanwhile, quantitative analysis is applied through dummy regression modeling to see what factors influence farmer financial literacy. The following hypotheses have been constructed in this study.

$\mathrm{H}_{1}$ : Age negatively influences the level of farmer's financial literacy.

$\mathrm{H}_{2}$ : Income positively influences the level of farmer's financial literacy.

$\mathrm{H}_{3}$ : Level of education positively influence the level of farmer's financial literacy.

These 3 variables which are taken into consideration as independent variables that are thought to affect the financial literacy of farmers are based on research conducted by Ravikumar et.al (2013) and Anwar (2011).

Multiple regression estimates the parameter using ordinary least square (OLS) estimation. OLS estimators will produce the best linear unbiased estimator if the regression classic assumptions are met. The following equation is constructed of the farmer's financial literacy function.

$$
F L_{i}=\beta_{0}+\beta_{1} \text { Age }+\beta_{2} \text { dummyeduction }+\beta_{3} \text { Income }+\varepsilon
$$

$F L_{i}$ is the level of financial literacy on farmers $1,2,3, \ldots \mathrm{n} ; \beta_{0}, \beta_{1}, \beta_{2}, \beta_{3}$ is the parameters to be estimated; variable of age is in years, $\varepsilon$ is an error.

The level of financial literacy of farmers is measured by an index that is built from the answers to a series of questions related to the financial literacy components mentioned above. The formula used to calculate the financial literacy index is as follows (Yarasevika, 2016):

$$
\text { Farmers financial literacy }=\frac{\text { index } 1+\text { index } 2+\text { index } 3}{3}
$$

Index 1 represents farmer's financial knowledge; index 2 represents farmer's financial behavior; index 3 represents farmer's financial attitude.

\section{Result and Discussion}

Based on the survey results, it is known that the main income of the respondents is from farming, which is $77 \%$, although some others have additional businesses/jobs, which is $23 \%$. Other additional jobs that the respondents have been as civil servants (working in government agencies), and as entrepreneurs. Therefore, it can be concluded that the main income of the respondents comes from the results of their farming. If the yield of the farm/harvest is good, the selling price of the harvest will also be at a normal or high level so that the farmer has the opportunity to benefit from this result. Otherwise, the selling price is low and the farmers will suffer losses. This is what is of great concern so that it is necessary to know the level of farmer literacy and the factors that influence it. Below is table 1 showing the demographic characteristic of the farmers.

Based on table 1, the majority of respondents are of the productive age and male. As many as 81.1 percent of respondents are married and the rest are divorced and single. The majority of respondents' education level is senior high school graduates (43.4 percent), while the least respondents are 
university graduates (26.4 percent). The monthly income level of the most dominant respondents is low income at 84,9 percent, others are classified as medium income at 13,2 percent and high income at 1,9 percent. The largest percentage comes from farmers with low income per month, which may come from labor farmers. In fact, farmers who own agricultural land also have low incomes which may be due to low or fluctuating selling prices and these farmers rarely get profit. It is possible for the farmer with low income to not be able to set aside his money to save or even invest in financial institutions. The farmer's income is actually not a routine income per month but rather a seasonal income depending on the harvest schedule. In this case, we asked the respondents the income from the harvest per year which is then calculated by dividing it into an estimated monthly income. The majority of farmers own land of fewer than $1000 \mathrm{~m} 2$ as much as 66.1 percent, and the least farmers own land with an area of more than $30000 \mathrm{~m} 2$.

Table 1. Respondents Demographic Characteristics

\begin{tabular}{|c|c|c|}
\hline Characteristics & Socio-Economic Category & Percentage \\
\hline \multirow[t]{2}{*}{ Age } & Productive (15-59 years old) & $94,3 \%$ \\
\hline & Elderly (Over 59 years) & $5,7 \%$ \\
\hline \multirow[t]{2}{*}{ Gender } & Female & $32,1 \%$ \\
\hline & Male & $67,9 \%$ \\
\hline \multirow[t]{3}{*}{ Marital status } & Married & $81,1 \%$ \\
\hline & Single & $16,9 \%$ \\
\hline & Divorcee & $0,02 \%$ \\
\hline \multirow[t]{5}{*}{ Last Education } & Primary School & $18,9 \%$ \\
\hline & Junior High School & $9,4 \%$ \\
\hline & Senior High School & $43,4 \%$ \\
\hline & Diploma I/II/III & $1,9 \%$ \\
\hline & Diploma IV/Bachelor & $26,4 \%$ \\
\hline \multirow[t]{5}{*}{ Farmer Status } & Farm Worker & $15,1 \%$ \\
\hline & Cultivator farmers & $15,1 \%$ \\
\hline & Landowner & $24,5 \%$ \\
\hline & Landowner as well as a cultivator & $41,5 \%$ \\
\hline & Tenant farmer & $3,8 \%$ \\
\hline \multirow[t]{3}{*}{ Income } & Low $(<$ IDR 2,5 million & $84,9 \%$ \\
\hline & Middle (IDR 2,5-10 million) & $13,2 \%$ \\
\hline & High (> IDR 10 million) & $1,9 \%$ \\
\hline \multirow[t]{4}{*}{ Land $\left(\mathrm{m}^{2}\right)$} & $\leq 1.000$ & $66,1 \%$ \\
\hline & $>1.000-5.000$ & $11,3 \%$ \\
\hline & $>5.000-10.000$ & $11,3 \%$ \\
\hline & $>10.000$ & $11,3 \%$ \\
\hline
\end{tabular}

Source: Author's analysis

Based on the survey results, $2 \%$ of respondents who have a farming business in the form of vegetables are also respondents. Respondents who have farming in the form of coffee plants are $51 \%$. The owner of the farm in the form of rice fields is $16 \%$ and in the form of rubber plants is $6 \%$. The rest are farm owners with 2 or more types of crops, namely rice and rubber, rice and coffee, coffee and rubber, vegetables and pepper, and fruits. 
Respondents who are the target of this study are farmers who have been involved in agriculture for a long time. Respondents with 0-5 years of farming experience were $24 \%,>5-10$ years were $29 \%,>10$ years were $47 \%$.

The utility level of farmers' financial products in the study locations is quite low, namely less than 50 percent on average, except for savings products which have a utility rate of 32 percent. However, the utility rate of one of the financial products that are closely related to agriculture, namely agricultural insurance is $11 \%$. Only $13 \%$ of farmers have bank credit to buy agricultural equipment, vehicles to transport crops, or even to buy and open new agricultural land. The farmer who sets aside a portion of his income from his harvest which is then invested in time deposits is $7.5 \%$. Whereas farmers who plan for their retirement by opening a pension fund account are only $2 \%$, shows the lowest number compared to another finance product. In fact, there are still farmers who do not have any financial products with a zero utility level of $26.5 \%$, which is quite large.

The results of the analysis in table 2 show that the majority of farmers in the study locations were included in the quite literate category as much as 47.2 percent. About 22.6 percent of farmers have a good literacy rate. Farmers who are classified as quite financially literate are farmers who manage their finances but not routinely. Sometimes they save, record household income and expenses, set aside for investment in the form of deposits but sometimes they don't. Meanwhile, there are still farmers who have a poor literacy rate of 24.5 percent. Farmers with low financial literacy do not carry out financial management by recording expenses per month and do not plan finances for the future. This is because their income still does not cover their basic needs, so they think they don't need to do financial management and planning. The least farmers in the research location were included in the very well literate category of 5.7 percent of the total respondents. Farmers with good financial literacy routinely manage family finances, have a deposit portfolio at a bank, and even have agricultural insurance to protect themselves from the risk of loss of crop failure. The recording of household income and expenditure is mostly carried out by the wife or housewife.

Table 2 Farmers' Financial Literacy Level

\begin{tabular}{|c|c|}
\hline Category & Percentage \\
\hline Not literate & $0 \%$ \\
\hline Less literate & $24,5 \%$ \\
\hline Quite literate & $47,2 \%$ \\
\hline Well literate & $22,6 \%$ \\
\hline Very well literate & $5,7 \%$ \\
\hline
\end{tabular}

Source: Author's analysis

The analysis of the most dominant components of financial literacy based on table 3 shows the conclusion that the financial attitude index contributed the most to the farmers' financial literacy index, namely 0.73 . Meanwhile, the average index of financial knowledge of farmers was 0.48 and the average index of financial behavior was 0.35 .

Table 3 Farmers' Financial Literacy Components

\begin{tabular}{|c|c|}
\hline Category & Index Mean \\
\hline Financial knowledge & 0,48 \\
\hline Financial behavior & 0,35 \\
\hline Financial attitude & 0,73 \\
\hline
\end{tabular}

Source: Author's analysis

Model feasibility testing is done by analyzing the significance value. $F$ statistical test with a significance value $(\mathrm{Sig})<(\alpha) 0.05$, the hypothesis is accepted. This shows that the independent variables used, namely the amount of income, age, and level of education simultaneously have a significant effect on the dependent variable, namely financial literacy. 
Calculating the coefficient of determination $\left(R^{2}\right)$ The coefficient of determination used in this study is $R$ Square. The results of data processing to see the factors that affect the level of financial literacy of farmers, using multiple linear regression analysis methods, the coefficient of determination shows an $\mathrm{R}$-Square value of 0.332 , which means that the independent variables are income level, age, education level, dummy. Farmer's income level, age, and education level were able to explain 33.2 percent of the dependent variable, namely financial literacy, and the remaining 66.8 percent was explained by other variables not examined.

Table 4 Significance of the Coefficients

\begin{tabular}{|c|c|c|c|c|}
\hline & Coefficient & Std. Error & t Statistics & Significance \\
\hline Intercept & 0.504 & 0.07 & 7.35 & $1.9 \mathrm{E}-09$ \\
\hline Age & -0.002 & 0.00 & -1.16 & 0.25 \\
\hline Education $^{*}$ & 0.034 & 0.01 & 3.19 & 0.00 \\
\hline Income & 0.032 & 0.02 & 1.32 & 0.19 \\
\hline
\end{tabular}

Source: Author's analysis

*) Significant at $5 \%$

Based on table 4, the income variable has a positive effect on the financial literacy index of farmers with an estimation coefficient of 0.032 at the 1 percent real level. That is, a 1 percent increase in income will increase financial literacy by 0.032 , ceteris paribus. This is in line with the research of Aggarwal et al. (2014) which states that farmers with high incomes have a higher level of financial literacy than low-income farmers. But in this study, the income variable is insignificant toward the financial literacy index of farmers.

The age variable has also no significant effect on the farmer's financial literacy index. This indicates that the level of financial literacy index does not depend on a person's age. The results of this study are in line with the results of research by Anwar et al. (2020) and Aggarwal et.al (2014) (Aggarwal, Gupta, \& Singh, 2014, Qureshi, Muhammad Imran, et al. (2020) which state that age does not have a significant effect on farmer financial literacy. The higher the age of the farmers does not affect the level of financial literacy as hypothesized because there are farmers who are at the age of 50 but only had their last education, namely elementary school.

The dummy variable of education level has a positive influence on the financial literacy index with an estimator coefficient of 0.011 at the 1 percent real level. This means that an increase in 1 year of education will increase financial literacy by 0.011 . This is consistent with the research of Ravikumar et al. (2013) and Anwar, Putri, \& Sabir (2020) which state that the higher the education of farmers, the higher the level of financial literacy.

\subsection{Policy Implication}

In this study, it was found that most of the farmers in Lahat were at the quite literate level on finance, namely as much as $47.2 \%$, and less literate as much as $24.5 \%$. Besides, farmer's financial knowledge index is at 0.48 and financial behavior is 0.35 which are categorized as very low. Financial literacy includes many things, such as the ability to read, analyze, manage, communicate financial conditions that can adversely affect welfare. Basic knowledge related to financial concepts is very important for society to survive in an increasingly sophisticated era. This basic knowledge includes the ability and confidence of the public to manage their finances by making short-term decisions and longterm planning by taking into account economic developments and changing situations and conditions in general.

Given the importance and strategic importance of financial literacy for the Indonesian people in general and farmers in Lahat Regency in particular, the local government, in this case, the Agriculture Office, needs to develop policies to improve farmers' financial literacy through various promotions and training as well as financial management practices. The key to the success of this policy will depend on the content of the training, effective methods, active participation of farmers, and support from 
community leaders. Facilities from local officials, such as the District Office and the Village Head, also greatly determine the success of the implementation of this policy.

Surveillance or monitoring of the effectiveness of the implementation of the policy must be carried out in a structured manner, starting from the material, training methods, participant selection, adequate time and place, and measurable achievements from the community. The results of this monitoring are submitted to the Department of Agriculture as the policymaker to be used as feedback so that the policy becomes more effective and efficient in the future.

It is very possible that this policy will not run smoothly for various reasons. First, the training materials and methods were not well designed. Here a team of experts is needed to compile materials and design training methods. Second, the active participation of the community is not strong enough, the community is reluctant to participate in financial literacy training. In this case, the role of community leaders is necessary to ensure that financial literacy is important and necessary to strengthen their financial management which in turn will improve their economic conditions. Third, the sectoral ego causes the agriculture sector to pay less attention or even less support for the policy. Here, the role of the Regional Head is needed to emphasize the importance of inter-sectoral coordination and strong support for farmer welfare.

This study also found that education had a significant effect on farmers' financial literacy. One indicator of a financially literate farmer is that they have financial knowledge. Of course, the higher a person's knowledge of finance, the higher the level of education. Thus, the higher the level of education of a farmer, the more literate his finances are. Farmers with a high level of education have a better understanding of financial or economic issues. Therefore, the local government of the Lahat Regency, in this case, the Education Office, needs to develop a policy to campaign more about the importance of going to school and encourage highly educated people to start working in the world of agriculture. The agricultural sector in Lahat Regency looks promising because this area is classified as fertile and is located in the highlands which is very suitable for planting rice, coffee, rubber, vegetables, and other crops.

The key to the success of this policy is the decrease in dropout rates and an increase in the number of educated people to start becoming farmers. Monitoring the effectiveness of the implementation of this policy must be carried out in a structured and systematic manner. The results of this monitoring are conveyed to the Education Office as the policymaker to be used as feedback so that the policy becomes more effective and efficient in the future. Various things cause the implementation of the quality of the policy to run poorly. First, increasing dropout rates. In this case, the participation of various parties, namely the local government and schools in the district, is needed to provide guidance and assistance in learning. Second, the lack of active participation from the community, namely those with higher education are reluctant to become farmers. In this case, the role of community leaders is necessary to ensure that running agricultural business activities in the Lahat Regency is a very promising thing that can improve the economy which in turn can increase farmers' financial literacy. Third, the sectoral ego causes the education office to pay less attention and maybe even less support for the policy. Here the role of the Regional Head is needed to oversee inter-sector coordination.

\section{Conclusion}

The majority of farmers in the research location fall into the quite financial literacy category, which is 47.52 percent of the total respondents. The financial attitude index is the largest contributor to the farmers' financial literacy index. The average index of financial attitudes owned by farmers was 0.73 , while the average index value of the respondent's financial knowledge was 0.48 and the average index value of the respondent's financial behavior was 0.35 .

Most of the respondents already know and have or are currently using savings financial products but the use of other financial service products is still relatively small. Farmers still limit the use of credit (only $13 \%$ ) if they experience financial difficulties. In managing finances, such as borrowing a certain amount of funds, farmers rely more on loans from friends or family, while for large loans, many farmers 
have made loans at banks but limit the amount of loans (credit). Meanwhile, other financial products and services such as insurance and farmer pension funds are still limited to the farmer's financial knowledge which is quite low, and the absence of insurance companies and pension funds in the village where the farmer lives. They need to go to the central region to find various financial institutions which take 1-2 hours ride from the village. There are still many farmers who have low incomes so that they are not able to channel their income to these financial products. For time deposits, current accounts, and mobile banking products, farmers still don't really understand and most of them still need information about these financial products.

The policy implication that can be recommended by this research is that the government must support the improvement of farmers' financial literacy by issuing policies in the financial sector related to agriculture. Inviting academics to provide socialization, education, training, and workshops so that farmers become more financially literate and their products are sustainable. The Indonesian Financial Services Authority and parties that carry out financial business activities work together to socialize their roles and functions for farmers.

\section{References}

1. Aggarwal, N., Gupta, M., \& Singh, S. (2014). Financial Literacy among Farmers : Empirical Evidence from Punjab. PAcific Business Review International, 6(7), 36-42.

2. Anwar, A. I., Putri, R., \& Sabir, S. (2020). Analisis Faktor-Faktor Yang Mempengaruhi Literasi Keuangan Pada Petani Tanaman Pangan dan Holtikultura di Kabupaten Maros Sulawesi Selatan. EJournal Ekonomi Bisnis Dan Akuntansi, 7(2), 125. https://doi.org/10.19184/ejeba.v7i2.18898

3. Atkinson, A., \& Messy, F. (2013). PROMOTING FINANCIAL INCLUSION THROUGH FINANCIAL EDUCATION.pdf. OECD Publishing, (34). https://doi.org/10.1787/5k3xz6m88smp-en

4. Carpena, F., \& Zia, B. (2011). Unpacking the Causal Chain of Financial Literacy. The World Bank Development Research Group, (September), 1-36.

5. Huston, S. J. (2010). Measuring Financial Literacy. Journal of Consumer Affairs, 44(2), 296-316. https://doi.org/10.1111/j.1745-6606.2010.01170.x

6. OECD. (2006). The Importance of Financial Education. Retrieved October 26, 2020, from http://www.oecd.org/finance/financial-education/37087833.pdf

7. Otoritas Jasa Keuangan. (2017). STRATEGI NASIONAL LITERASI KEUANGAN INDONESIA ( Revisit 2017).

8. Palameta, B., Nguyen, C., Hui, T. S., \& Gyarmati, D. (2016). The Link between Financial Confidence and Financial Outcomes among Working-Aged Canadians for the Financial Consumer Agency of Canada. The Social Research and Demonstration Corporation, (May), 1-63.

9. Ravikumar, R., Sivakumar, S. D., Jawaharlal, M., Palanichamy, N. V., \& Sureshkumar, D. (2013). Assessment of Farm Financial Literacy among Jasmine Growers in Tamilnadu, India. Developing Country Studies, 3(13), 67-75. Retrieved from https://www.iiste.org/Journals/index.php/DCS/article/view/9413

10.Qureshi, Muhammad Imran, et al. "Classifications of sustainable manufacturing practices in ASEAN region: A systematic review and bibliometric analysis of the past decade of research." Sustainability 12.21 (2020): 8950.

11.Remund, D. L. (2010). Financial literacy explicated: The case for a clearer definition in an increasingly complex economy. Journal of Consumer Affairs, 44(2), 276-295. https://doi.org/10.1111/j.17456606.2010.01169.x

12.Sri, J. (2019). Poverty level of farmers based on total income and feasibility of rice farming. World Journal of Advanced Research and Reviews, 04(02), 082-089. https://doi.org/10.30574/wjarr

13.Statistics Indonesia. (2015). Produk Domestik Bruto Atas Dasar Harga Konstan 2000 Menurut Lapangan Usaha (Miliar Rupiah), 2000-2014. Retrieved from 
https://www.bps.go.id/statictable/2009/07/02/1200/-seri-2000-pdb-atas-dasar-harga-konstan2000-menurut-lapangan-usaha-miliar-rupiah-2000-2014.html

14.Tustin, D. H. (2010). An impact assessment of a prototype financial literacy flagship programme in a rural South African setting, 4(August), 1894-1902.

15.Xu, L., \& Zia, B. (2012). Financial Literacy Around the World: An Overview of the Evidence with Practical Suggestions for the Way Forward. SSRN Electronic Journal, (June). https://doi.org/10.2139/ssrn.1810551

16.Yarasevika, S. (2016). Evaluasi Tingkat Literasi Keuangan Petani Padi Dan Hortikultura Di Kabupaten Tasikmalaya Dan Garut. Institut PErtanian Bogor.

17.Yuwono, M., Suharjo, B., Sanim, B., \& Nurmalina, R. (2017). Analisis Deskriptif Atas Literasi Keuangan Pada Kelompok Tani. EKUITAS (Jurnal Ekonomi Dan Keuangan), 1(3), 407. https://doi.org/10.24034/j25485024.y2017.v1.i3.2400 